JUSTITIA : Jurnal Ilmu Hukum dan Humaniora

issn cetak :2354-9033 || issn online :2579-9398 || Vol. 1 No. 2 Tahun 2019

http://jurnal.um-tapsel.ac.id/index.php/justitia

\title{
Proses Penyelesaian Sengketa Hak Tas Tanah Melalui Mediasi Di Kantor Pertanahan Kota
}

\author{
Marwan Busyro1), Ridwan Rangkuti 2) \\ Fakultas Hukum UMTS Padangsidimpuan \\ Korespondensi: marwan.busyro@um-tapsel.ac.id
}

\begin{abstract}
Abstrak
Tujuan penelitian ini adalah untuk mengetahui bagaimana proses penyelesaian sengketa hak atas tanah melalui mediasi dan apa saja hambatan proses penyelesaian sengketa hak atas tanah melalui mediasi di Kantor Pertanahan Kota Padangsidimpuan. .Dari hasil penelitian dan pembahasan diperoleh kesimpulan bahwa prosedur atau tata cara penyelesaikan sengketa yang dilakukan oleh Kantor Pertanahan meliputi tahap (1) pra mediasi, (2) mediasi. Dalam penyelesaian sengketa hak atas tanah di Kantor Pertanahan Kota Padangsidimpuan memiliki beberapa hambatan-hambatan, yaitu (1) adanya kendala dari pihak yang bersengketa seperti, ketidakhadiran para pihak untuk memenuhi undangan untuk melakukan mediasi (2) tidak ada iktikad baik dari masing-masing pihak (3) perbedaan kemampuan dan pendidikan di antara para pihak (4) aturan yang dianggap memperlambat proses penyelesaian sengketa (5) pengadu sering kali tidak mengetahui persyaratan dan prosedur penyelesaian sengketa di Kantor Pertanahan Kota Padangsidimpuan.
\end{abstract}

\section{Kata-kata Kunci: $\quad$ Proses Penyelesaian Sengketa; Mediasi; Kantor} Pertanahan

\begin{abstract}
The purpose of this study is to find out how the process of resolving disputes over land rights through mediation and what are the obstacles to the process of resolving disputes over land rights through mediation at the Padangsidimpuan City Land Office. From the results of the research and discussion, it can be concluded that the procedures or procedures for resolving disputes conducted by the Land Office include stages (1) premediation, (2) mediation. In resolving disputes over land rights at the Padangsidimpuan City Land Office, there are several obstacles, namely (1) the existence of obstacles from the disputing parties such as the absence of parties to fulfill the invitation to mediate (2) there is no good intention from each party (3) differences in ability and education among the parties (4) rules deemed to slow down the dispute resolution process (5) complainants often do not know the requirements and procedures for dispute resolution at the Padangsidimpuan City Land Office.
\end{abstract}

Key words: Process of Dispute Resolution, Mediation, Land Office. 


\section{PENDAHULUAN}

Tanah atau wilayah merupakan unsur utama dari suatu negara.Bagi bangsa Indonesia yang merupakan suatu Negara yang disebut sebagai bangsa agraris atau pun kepulauan, tanah mempunyai kedudukan yang sangat penting dalam rangka penyelenggaraan hidup dan kehidupan manusia. Hal ini dapat dimengerti dan dipahami, karena tanah merupakan tempat tinggal, tempat mendapatkan makanan, tempat mereka dilahirkan, tempat ia dimakamkan bahkan tempat leluhurnya, maka selalu ada pasangan antara manusia dengan tanah, antara masyarakat dengan tanah.

Dalam Pasal 16 ayat (1) Undang-undang Nomor 5 Tahun 1960 tentang Peraturan dasar Pokok-Pokok Agraria atau biasa disebut Undang-Undang Pokok Agraria yang berbunyi :

(1) Hak-hak atas tanah sebagai yang dimaksud dalam Pasal 4 ayat 1 ialah:

a. Hak milik,

b. Hak guna usaha,

c. Hak guna bangunan,

d. Hak pakai,

e. Hak sewa,

f. Hak membuka tanah,

g. Hak memungut hasil hutan,

h. Hak-hak lain yang tidak termasuk dalam hak-hak tersebut diatas yang akan ditetapkan dengan Undangundang serta hak-hak yang sifatnya sementara sebagai yang disebutkan dalam Pasal 53

Dengan konsep Negara Kesatuan Republik Indonesia tahun 1945, maka tidak akan terlepas dari sengketa hukum atas tanah yang merupakan permasalahan mendasar dalam masyarakat khususnya dibidang yang menyangkut tanah. Dalam bentuk Negara yang demikian, pemerintah akan memasuki hampir seluruh aspek kehidupan dan penghidupan rakyat, baik sebagai perorangan maupun sebagai masyarakat. Dalam kenyataan sehari-hari permasalahan tanah muncul dan dialami oleh seluruh lapisan masyarakat. Sengketa pertanahan merupakan isu yang selalu muncul dan selalu aktual dari masa ke masa, seiring dengan bertambahnya penduduk, perkembangan pembangunan dan semakin meluasnya akses berbagai pihak untuk memperoleh tanah sebagai modal dasar dalam berbagai kepentingan. Masalah pertanahan merupakan suatu permasalahan yang cukup rumit dan sensitif sifatnya karena menyangkut berbagai aspek kehidupan baik bersifat sosial, ekonomi, politis sehingga dalam penyelesaian masalah pertanahan bukan hanya harus memperhatikan aspek yuridis akan tetapi juga harus memperhatikan berbagai aspek kehidupan lainnya agar supaya 
penyelesaian persoalan tersebut tidak berkembang menjadi suatu keserahan yang dapat menggangu stabilitas masyarakat.

Munculnya berbagai masalah mengenai tanah menunjukan bahwa penggunaan, penguasaan dan pemilikan tanah di Negara kita ini belum tertib dan terarah. Masih banyak penggunaan tanah yang saling tumpang tindih dalam berbagai kepentingan yang tidak sesuai dengan peruntukannya.Fakta juga menunjukkan bahwa penguasaan dan pemilikan tanah masih timpang.Ada sekelompok kecil masyarakat yang memiliki tanah secara liar dan berlebihan dan ada juga sekelompok besar masyarakat yang hanya memiliki tanah dalam jumlah sangat terbatas. Bahkan banyak pula yang sama sekali tidak memiliki.

Pengaduan-pengaduan masalah pertanahan pada dasarnya merupakan suatu fenomena yang mempersoalkan kebenaran suatu hukum yang berkaitan dengan pertanahan.Hal ini dapat berupa produk-produk pertanahan tersebut, riwayat perolehan tanah, penguasaan, pemilikan, penggunaan dan pemanfaatan tanah, pembebasan tanah dan sebagainya.Tanah perlu ada pengaturannya serta lembaga Negara yang secara khusus berkecimpung dan berwenang dalam pertanahan ataupun masalah penanganan pertanahan. Sesuai dengan Peraturan Presiden nomor 10 Tahun 2006, dikuatkan atas pembentukan Badan Pertanahan Nasioanal (BPN) yang disusun dengan memperhatikan sisi dan aspek aspirasi dan peran serta masyarakat guna dapat menunjang kesejahteraan umum. Sehingga Badan Pertanahan nasioanal berperan dalam membantu dan melayani masyarakat dalam mendapatkan haknya dibidang pertanahan, serta dalam membantu masyarakat untuk dapat menemukan jalan penyelesaian bilamana terdapat sengketa antar masyarakat mengenai haknya dibidang pertanahan.

Selain penyelesaian sengketa melaui pengadilan/litigasi, di dalam sistem hukum nasional dikenal dengan penyelesaian sengketa melalui lembaga diluar peradilan sebagaimana yang diatur dalam Undang-undang Nomor 30 Tahun 1999 tentang Arbitrase dan Alternatif Penyelesaian Sengketa sebagaimana yang dikemukakan oleh Rachmadi Usman : "Salah satu alternatif penyelesaian sengketa (tanah) adalah melalui upaya mediasi. Mediasi sebagai penyelesaian sengketa alternatif menawarkan cara penyelesaian sengketa yang khas. Karena prosesnya relatif sederhana, maka waktunya singkat dan biaya dapat ditekan". ${ }^{1}$

Berkenaan dengan sengketa hukum dengan pertanahan, penyelesaian sengketa melalui jalur di luar pengadilan atau secara alternatif sangatlah memungkinkan dan relavan. Secara lingkup formal Badan Pertanahan Nasional melalui Peraturan Presiden

\footnotetext{
${ }^{1}$ Rachmadi Usman, Pilihan Penyelesaian Sengketa di Luar Pengadilan, PT. Citra Aditya Bakti, Bandung,2003, hal.3
} 
Nomor 10 Tahun 2006 tentang Badan Pertanahan Nasional telah membentuk deputi Bidang Pengkajian dan Penanganan Sengketa dan Konflik Pertanahan dalam struktur organisasi Badan Pertanahan Nasional. Dalam teknis pelaksanaannya Badan Pertanahan Nasional telah menerbitkan Petunjuk Teknis Penanganan dan Penyelesaian Masalah Pertanahan melalui Keputusan Kepala BPN RI Nomor 34 Tahun 2007.Terbaru yang keluar adalah Peraturan Menteri Agraria dan Tata Ruang/Kepala Badan Pertanahan Nasional Republik Indonesia Nomor 11 Tahun 2016 tentang Penyelesaian Kasus Pertanahan.

Mengingat bahwa bangsa Indonesia terkenal dengan penyelesaian masalah melalui musyawarah untuk mencapai mufakat, kiranya pemanfaatan lembaga mediasi dapat merupakan alternatif yang berdampak positif untuk penyelesaian sengketa pertanahan.

\section{PEMBAHASAN}

\section{Proses Penyelesaian Sengketa Hak Atas Tanah Melalui Mediasi Di Kantor Pertanahan Kota Padangsidimpuan}

Badan Pertanahan Nasional merupakan lembaga pemerintah yang bertugas untuk melaksanakan dan mengembangkan administrasi pertanahan.Dalam melaksanakan tugas tersebut, penyelesaian masalah pertanahan merupakan salah satu fungsi yang menjadi kewenangan Kantor Pertanahan.Penyelesaian sengketa tanah melalui mediasi di Kantor Pertanahan perlu dilandasi dengan kewengangan yang sah berdasarkan peraturan perundang-undangan. Berdasarkan hasil penelitian dan wawancara, menerangkan bahwa penyelesaian sengketa, konflik dan perkara pertanahan secara efektif telah ditetapkan Peraturan Menteri Agraria dan Tata Ruang/Kepala Badan Pertanahan Nasional Republik Indonesia Nomor 11 Tahun 2016 tentang Penyelesaian Kasus Pertanahan. Keputusan Badan Pertanahan Republik Indonesia Nomor 11 Tahun 2009 tentang kebijakan dan Strategi Kepala BPN Republik Indonesia Menangani dan Menyelesaiakan Sengketa, Konflik dan Perkara Pertanahan Tahun 2009, dimana sistem penanganan masalah Pertanahan dengan pedoman kepada Keputusan Kepala Badan Pertanahan Nasional Nomor 34 Tahun 2007 tentang petunjuk Teknis Penanganan dan penyelesaian Masalah Pertanahan. Salah satu metode penyelesaian kasus pertanahan ditetapkan melalui Mediasi dimana mekanisme pelaksaan Mediasi diatur di dalam Petunjuk Teknis Badan Pertanahan Nasional Republik Indonesia Nomor : 05/JUKNIS/D.V/2007 (Keputusan Kepala BPN Republik Indonesia Nomor 34 Tahun 2007) tentang Mekanisme Pelaksanaan Mediasi yang dikeluarkan di Jakarta pada tanggal 31 Mei 2007. Dasar hukum kewenangan Badan Pertanahan Nasional/Kementerian 
Agraria dan Tata Ruang telah tercantum dalam Peraturan Menteri Agraria dan Tata Ruang/Kepala Badan Pertanahan Nasional Republik Indonesia Nomor 11 Tahun 2016 tentang Penyelesaian Kasus Pertanahan. Penyelesaian sengketa dan konflik dilakukan berdasarkan inisiatif dari Kementerian dan pengaduan masyarakat. Dalam menyelesaikan kasus pertanahan Penanganan Masalah dan Pengendalian Pertanahan menerangkan bahwa maksud penyelesaian kasus pertanahan sebagai berikut:

a) mengetahui riwayat dan akar permasalahan Sengketa, Konflik atau Perkara;

b) merumuskan kebijakan strategis penyelesaian Sengketa, Konflik atau Perkara; dan

c) menyelesaikan Sengketa, Konflik atau Perkara, agar tanah dapat dikuasai, dimiliki, dipergunakan dan dimanfaatkan oleh pemiliknya

Penyelesaian Kasus Pertanahan bertujuan untuk memberikan kepastian hukum dan keadilan mengenai penguasaan, pemilikan, penggunaan dan pemanfaatan tanah. Penangan masalah pertanahan melalui lembaga mediasi oleh BPN biasanya didasarkan dua prinsip utama, yaitu:

a) Kebenaran-kebenaran formal dari fakta-fakta yang mendasari permasalahan yang bersangkutan;

b) Keinginan yang bebas dari para pihak yang bersengketa terhadap objek yang disengketakan.

Sebagai mediator, BPN mempunyai peran membantu para pihak dalam memahami penadangan masing-masing dan membantu mencari hal-hal yang dianggap penting bagi mereka.Mediator mempermudah pertikaran informasi, mendorong diskusi mengenai perbedaan-perbedaan kepentingan, persepsi, penafsiran terhadap situasi dan persoalan-persoalan dan mengatur pengingkapan emosi. Adapun bentuk dari berita acara tersebut adalah sebagai berikut:

a) Judul, yang dimaksud judul disini adalah kegiatannya, obyek dan letak tanahnya nsecara jelas, sehingga tidak menimbulkan kerancuan atau tidak sesuai dengan maksudnya;

b) Hari tanggal kegiatan, yang dimaksud adalah hari dan tanggal pelaksanaan kegiatan yang dimaksud didalam berita acara tersebut;

c) Dasar pelaksanaan kegiatan, disebutkan dasar pelaksanaan kegiatan musyawarah tersebut maksudnya adalah pelaksanaan orang yang ditugasi untuk melakukan musyawarah atau mediasi tersebut;

d) Orang yang ditugasi untuk melaksanakan kegiatan, disebutkan nama dan identitas kedinasan dari orang yang ditugasi melaksanakan musyawarah sesuai dengan Surat Keputusan;

e) Jenis kelamin, disebutkan jenis kegiatan yang telah dilaksanakan; 
f) Pihak-pihak yang hadir, pihak yang hadir disebutkan pula didalam Berita Acara tersebut;

g) Hasil Kegiatan, yang dicantumkan merupakan kesimpulan dari musyawarah yang telah dilaksanakan tersebut;

h) Ketentuan Penutup, bagian ini hanya memuat kalimat penutup berita acara tersebut;

a. Tanda Tangan, yang menandatangani Berita Acara adalah orang yang ditugasi sesuai dengan surat tugas yang mendasarinya atau orang yang melaksanakan tugas dimaksud oleh karena tidak semua yang hadir membubuhkan tanda tangan, maka sebagai kelengkapan Berita Acara tersebut;

b. Setelah dibuatnya Berita Acara maka pihak mediator dalam hal ini adalah BPN akan mengadakan mediasi dengan kedua belah pihak yang sedang bersengketa guna mendapatkan putusan yang saling menguntungkan dari kedua belah pihak;

c. Apabila kedua belah pihak yang bersengketa sepakat dengan putusan yang diberikan oleh seorang mediator, maka putusan tersebut akan ditindaklanjuti. Adapun penindaklanjutan putusan tersebut dengan perbuatanperbuatan administrasi yaitu penyelesaian sengketa itu sendiri. Adapun fungsi dari perjanjian perdamaian, berita acara, notulis maupun laporan tersebut merupakan dokumen tertulis sebagai dasar pertimbangan kepala BPN untuk merumuskan putusan penyelesaian sengketa yang diterima BPN, sedangkan realisasi fisik maupun administrasinya yaitu perubahan data sebagai akibat dari penyelesaian sengketa tersebut dilakukan oleh Kantor Pertanahan Kabupaten/Kota.

d. Putusan mediasi harus ditandatangani oleh para pihak, mediator dan saksi-saksi. Penandatanganan hekdanya dilakukan pada hari dan tanggal saat diambilnya putusan tersebut secara bersamaan dan tidak diperkenankan dilakukan secara terpisah. Salah satu cirri dari penyelesaian masalah dengan mediasi adalah putusannya merupakan kehendak yang dirumuskan secara bebas oleh para pihak.

Media boleh menentukan pilihan penyelesaian maslahnya karena itu putusan penyelesaian masalah dirumuskan dalam bentuk suatu kesepakatan (agreement).Akibat untung-rugi yang timbul dari putusan tersebut merupakan resiko sepenuhnya dari para pihak. Setiap lembaga penyelesaian sengketa mengandung keuntungan dan kekurangannya masing-masing, karena pendekatan penyelesaian yang dipergunakan berbeda-beda. Proses mediasi dalam rangka penyelesaian sengketa mengunakan pendekatan yang memberikan perhatian utama pada kepentingan-kepentingan 
yang berkaitan dengan persoalan yang diajukan oleh para pihak (interest based).

\section{Proses Penyelesaian Sengketa Secara Pra-Mediasi}

Berdasarkan hasil penelitian Penanganan Masalah dan Pengendalian Pertanahan menerangkan bahwa proses penyelesaian sengketa secara pra-mediasi, yaitu dengan tahap pengaduan. Pada tahap ini Kantor Pertanahan membuka ruang pengaduan bagi masyarakat di Kota Padangsidimpuan untuk menyampaikan aduannya terkait adanya permasalahan tanah yang mereka hadapi. Cara pengaduan dalam penyelesaian sengketa atau konflik tertuang pada Pasal 6 ayat (2) Peraturan Menteri Agraria dan Tata Ruang/Kepala Badan Pertanahan Republik Indonesia No.11 Tahun 2016 adalah sebagai berikut: "pengaduan sebagaimana dimaksud pada ayat (1) disampaikan kepada Kepala Kantor Pertanahan secara tertulis, melalui loket pengaduan, kotak surat atau website Kementerian. Pengaduan sebagaimana dimaksud pada ayat (2) paling sedikit memuat identitas pengadu dan uraian singkat kasus. Pengaduan sebagaimana dimaksud pada ayat (2) harus dilampiri dengan fotokopi identitas pengadu, fotokopi identitas penerima kuasa dan surat kuasa apabila dikuasakan, serta data pendukung atau bukti-bukti yang terkait dengan pengaduan.

\section{Proses Mediasi}

Setelah berbagai proses pra-mediasi telah dilalui, yang pada akhirnya menuntun untuk dilakukannya suatu mediasi demi terselesainya suatu permasalahan pertanahan. Berdasarkan hasil penelitian dan wawancara penulis dengan Kepala Seksi Penanganan Masalah dan Pengendalian Pertanahan menerangkan bahwa: dalam Peraturan Menteri Agraria dan Tata Ruang/Kepala Badan Pertanahan Nasional Republik Indonesia No.11 Tahun 2016 Pasal 38 ayat (2) pelaksanaan mediasi dilakukan paling lama 30 (tiga puluh) hari.

\section{PENUTUP}

Hasil penelitian menunjukkan bahwa Para pihak diminta untuk menyampaikan masalahannya serta opsi-opsi alternatif penyelesaian yang ditawarkan, sehingga ditarik benang merah permasalahannya agar proses negosiasi selalu terfokus pada persoalan (isu) tersebut. Potensi dalam sesi ini bisa terjadi kesalah pahaman baik mengenai permasalahannya, pengertian yang terkait dengan sengketanya atau hal terkait dengan pengertian status tanah Negara dan individualisasi.Perlu upaya/ kesepakatan untuk menyamakan pemahaman mengenai berbagai hal.Mediator dalam hal ini berperan dalam memberi koreksi jika pengertianpengertian persoalan yang disepakati tidak sesuai dengan peraturan perundang-undangan, agar tidak terjadi kesesatan.Setelah persoalan yang dapat menimbulkan misinter- 
prestasi diatasi, kemudian ditentukan agenda yang perlu dibahas (setelah diketahui persoalan yang melingkupi sengketa). Agenda musyawarah bermaksud agar proses musyawarah, diskusi, negosiasi dapat terarah dan tidak melebar/ keluar dari fokus persoalan mediator harus menjaga momen pembicaraan sehingga tidak terpancing atau terbawa/larut oleh pembicaraan para pihak. Mediator kemudian menyusun acara/agenda diskusi yang mencakup substansi permasalahan dan alokasi waktu

\section{Daftar Bacaan}

\section{Buku}

Budi Harsono, Hukum Agraria Indonesia, Sejarah Pembetukan UUPA, Isi dan Pelaksanaannya.Jakarta, 2003.

David Spencer, Michael Brogan, 2006:101-103, sebagaimana dikutip oleh Muslih MZ dalam Mediasi : Pengantar Teori Dan Praktek, www.hukumonline.com, online internet tanggal 20 Januari 2018

Effendi Perangin, Hukum Agraria Indonesia, Suatu Telaah Dari Sudut Pandang Praktis Hukum, Jakarta, Raja Grafindo, 1994

Elfachri Budiman, "Peradilan Agraria (Solusi Alternatif penuntasan Sengketa Agraria)" Jurnal Hukum USU Vol. 01. No.1, Tahun 2005

H. Hambali Thalib. Sanksi Pemidanaan dalam konflik pertanahan.Kencana. Bandung.2 009

Mochtar Wahid, Memaknai Kepastian Hukum Hak Milik Atas Tanah. Jakarta, 2008

Maria S.W. Sumardjono, "Tanah dalam Perspektif Hak Ekonomi Sosial Budaya” Jakarta : Kompas, 2008

Rachmadi Usman, Pilihan Penyelesaian Sengketa di Luar Pengadilan, PT. Citra Aditya Bakti, Bandung, 2003

Rusmadi Murad, Penyelesaian Sengketa Hukum Atas Tanah, Mandar Maju, Bandung: Mandar Maju, 1991

Samun Ismaya, Pengantar Hukum Agraria, Graha Ilmu, Yogyakarta

Syaiful Azam, "Eksistensi Hukum Tanah dalam mewujudkan tertib Hukum Agraria” Makalah Fakultas Hukum USU - Digitized by USU Digital Library, 2003.

Susanti Adi Nugroho, Mediasi Sebagai Alternatif Penyelesaian Sengketa, Edisi Pertama, Cetakan ke-1. Jakarta : Telaga Ilmu Indonesia, 2009 
Proses Penyelesaian Sengketa Hak Tas Tanah Melalui Mediasi Di Kantor Pertanahan Kota (Marwan Busyro, Ridwan Rangkuti)

\section{Undang-undang}

Undang-undang Nomor. 5 Tahun 1960, Tentang Peraturan Dasar Pokok-pokok Agraria

\section{Peraturan Menteri}

Peraturan Menteri Negara Agraria/Kepala Badan Pertanahan Nasional No.1 Tahun 1999, tentang Tata Cara Penanganan Sengketa Pertanahan

\section{Internet}

http://raypratama.blogspot.com/2012/02/hak-atas-tanah.html.

Diakses pada hari Senin, 11 Januari 2018, pukul 14.00 WIB 